\title{
MACULAR THICKNESS CHANGES FOLLOWING PANRETINAL PHOTOCOAGULATION IN PATIENTS WITH SEVERE DIABETIC RETINOPATHY
}

\author{
Bobbili Malleswari ${ }^{1}$, Nanda Asha Jyothi
}

${ }^{1}$ Associate Professor, Department of Ophthalmology, GMC, Suryapet, Telangana, India.

${ }^{2}$ Civil Assistant Surgeon, Department of Ophthalmology, Sarojini Devi Eye Hospital, Hyderabad, Telangana, India.

ABSTRACT
BACKGROUND
Diabetes is a metabolic disorder due to dysfunctional metabolism of glucose that arises out of the ineffective production or action
of the glucose-regulating enzyme called insulin. Type I diabetes results due to ineffective production and type II results due to the
in effective action of insulin. Diabetic retinopathy (DR) is a highly specific vascular complication of both type 1 and type 2 diabetes
mellitus. Diabetic retinopathy predominantly is a microangiopathy in which small blood vessels are particularly vulnerable to
damage from hyperglycaemia.

The aim of this study was to evaluate macular thickness changes occurring following PRP among severe Diabetic Retinopathy patients.

\section{MATERIAL AND METHODS}

This prospective observational study was conducted in Sarojini Devi Eye Hospital over a period of 24 months from November 2015 to October 2017. Patients with severe diabetic retinopathy - severe and very severe NPDR or PDR with or without macular oedema, who required PRP, were included in the study. OCT was done in all the patients included in the study before PRP. After completion of PRP, patients were followed up at 1 week, 1 month and 3 months and OCT was done at every visit.

\section{RESULTS}

Mean macular thickness at $1^{\text {st }}$ week, $1^{\text {st }}$ month and $3^{\text {rd }}$ month were compared to mean macular thickness before PRP and their variation were analysed. Patients with Macular Oedema- There is sudden increase in macular thickness at $1^{\text {st }}$ week following PRP and thereafter gradually decreased. Patients without Macular Oedema- There is sudden increase in macular thickness at $1^{\text {st }}$ week following PRP and thereafter gradually decreased. Mean macular thickness at $3^{\text {rd }}$ month were compared to mean macular thickness 1 st month after PRP and their changes were analysed. Macular thickness had further decreased at $3^{\text {rd }}$ month when compared to that at 1 st month and were highly significant.

\section{CONCLUSION}

PRP may cause transient changes in macular thickness in eyes with diabetic retinopathy associated with or without clinically significant macular oedema. The present study results suggest that macular oedema increased at 1 week in both the groups and decreased gradually at 1 month and 3 months. Greater rate of reduction of macular oedema was better appreciated in patients with clinically significant macular oedema.

\section{KEY WORDS}

Diabetic Retinopathy, PRP, Macular Oedema, OCT.

HOW TO CITE THIS ARTICLE: Malleswari B, Jyothi NA. Macular thickness changes following panretinal photocoagulation in patients with sever diabetic retinopathy. J. Evolution Med. Dent. Sci. 2018;7(48):5145-5149, DOI: 10.14260/jemds/2018/1142

\section{BACKGROUND}

Diabetes is a metabolic disorder due to dysfunctional metabolism of glucose that arises out of the ineffective production or action of the glucose-regulating enzyme called insulin. Type I diabetes results due to ineffective production and type II results due to the in effective action of insulin. Diabetic retinopathy (DR) is a highly specific vascular complication of both type 1 and type 2 diabetes mellitus. Diabetic retinopathy predominantly is a microangiopathy in which small blood vessels are particularly vulnerable to damage from hyperglycaemia.

'Financial or Other Competing Interest': None.

Submission 03-10-2018, Peer Review 08-11-2018,

Acceptance 15-11-2018, Published 26-11-2018.

Corresponding Author:

Bobbili Malleswari,

Flat No. 307, V. V. Vintage Residency,

Rajbhavan Road, Hyderabad-82,

Telangana, India.

E-mail: malleswari.bobbili@gmail.com

DOI: $10.14260 /$ jemds/2018/1142

\section{(c) (i) $(9)$}

Duration of diabetes is a significant risk factor for the development of retinopathy.(1) Diabetic retinopathy is the most common cause of blindness.

Panretinal photocoagulation (PRP) appears to be beneficial for patients with Proliferative Diabetic Retinopathy (PDR), as shown by the Diabetic Retinopathy Study and the Early Treatment Diabetic Retinopathy Study (ETDRS).(2) ETDRS study showed an approximate $50 \%$ reduction in the rate of moderate vision loss at 3 years following laser photocoagulation compared to no treatment.(3) For these reasons, PRP is increasingly being performed in clinical practice.

The Diabetic Retinopathy Study (DRS), the Early Treatment Diabetic Retinopathy Study (ETDRS) and the Diabetic Retinopathy Vitrectomy Study (DRVS) strongly supported the effective use of PRP in treating PDR and DME.

Despite the PRP benefits, the therapy procedure has some harmful side effects and complications, among them the most significant is the creation and exacerbation of macular oedema.(4) Macular thickness may increase after PRP with either transient or sustained decrease of vision. PRP 
increases leukocyte rolling and subsequent accumulation in both the photocoagulated and non-photocoagulated portions of the retina. These accumulated leukocytes are considered to augment vascular permeability in the untreated retina, and blood-retinal barrier breakdown which results in retinal oedema after photocoagulation.(5)

Nonaka et al suggested that all these changes occurred during a comparatively early phase after scatter photocoagulation corresponding to the macular oedema formation in the early phase and subsequently slowly reducing.(6) In present study, the macular thickness was measured by Optical Coherence Tomography (OCT). The interval between each session also depends on the patient's systemic or diabetic condition. Macular thickness may increase after PRP which is either transient or sustained.

The present study is undertaken to compare the changes in macular thickness before PRP to the macular thickness after PRP seen on follow up period of $1^{\text {st }}$ week, $1^{\text {st }}$ month and 3rd month.

\section{Aim of the Study}

To evaluate macular thickness changes following PRP among severe Diabetic Retinopathy patients.

\section{MATERIALS AND METHODS}

This prospective observational study was conducted in Sarojini Devi Eye Hospital over a period of 24 months from November 2015 to October 2017.

Study was conducted on 40 eyes with severe Diabetic Retinopathy undergoing PRP and evaluated for macular thickness changes occurring following PRP.

The changes in macular thickness before PRP were compared with the macular thickness after PRP seen on follow up period of $1^{\text {st }}$ week, $1^{\text {st }}$ month and $3^{\text {rd }}$ month using OCT.

\section{Inclusion Criteria}

- Both sexes above the age of 18 years with DM.

- Patients with severe diabetic retinopathy - severe and very severe NPDR or PDR with or without macular oedema.

- $\quad$ Patients willing for OCT and follow up.

\section{Statistical Analysis}

All the qualitative factors like Sex has been presented with the frequencies and percentages. All the quantitative parameters like Age, Duration of diabetics, and thickness of macula before PRP, and after PRP at different time points has been presented with means and standard deviation.

To compare the mean difference of age, duration of diabetics, and thickness of macula at different time points between 2 groups (patients with and without macular oedema) we used t-test for independent samples. To find the thickness change within the groups in different time points we used ANOVA for repeated measures.
All the Data Entered in MS. Excel and Analysed by using SPSS $19.0 \mathrm{v}$. $p$ value less than 0.05 will be considered as Significant-

- Data observed is shown in Tables and charts.

- Assessment of OCT in Present Study.

The Cirrus HD-OCT datasets used are 3D cubes centered on the macula. The 512x128 macular cube used for assessment. Within the analysis of the macular cube, an automated algorithm is used specifying the internal limiting membrane and the retinal pigment epithelium, layers used as the basis for the measurement of macular thickness and macular volume.

For segmentation, the ILM is first identified as the first highly reflective increase on the inner side. The RPE is found by identifying the 2 major peaks of each sampling line. The inner border of the second peak is the interface of the inner segment and outer segments of the photoreceptors. A gap close to this is detected as the inner border of the RPE/choroid. The distance between the ILM and inner border of the RPE/choroid is defined as the whole retinal thickness. The broadest area of lowest signal is defined as the outer retinal complex, consisting of the outer nuclear layer and inner and outer segments of the photoreceptors. The innermost prominent peak between the ILM and inner edge of the outer retinal complex is the macular RNFL layer. The outermost peak inside of the outer retinal complex is the outer plexiform layer. The remaining area from the outer border of the macular RNFL to the inner border of the outer plexiform layer is considered the inner retinal complex, consisting of the ganglion cells, inner plexiform layer, and inner nuclear layer.(7)

- Macular layer thickness values are calculated globally, as well as sectorally.

- Generally, global measurements are taken inside the outermost circle.

- In Present study, central subfoveal thickness was considered to evaluate and analyse macular thickness.

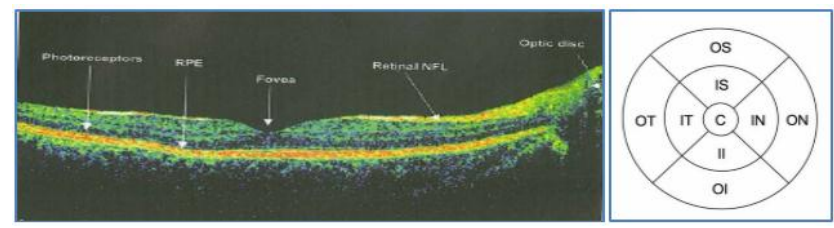

Figure 20: sectors indication in OCT of macula: Areas of macular thickness segmentation: $\mathrm{C}$, center; OS, outer superior; ON, outer nasal; OI, outer inferior; OT, outer temporal; IS, inner superior; IN, inner nasal; II, inner inferior; IT, inner temporal. Weighted mean is taken across the entire circle.

Massin. $\mathrm{P}$ et al observed that early detection of retinal abnormalities is vital in prevention of macular oedema and subsequent loss of vision. It was observed that OCT has a major role in the qualitative diagnosis of macular oedema and quantitative assessment of macular oedema and management.(8) 


\section{RESULTS}

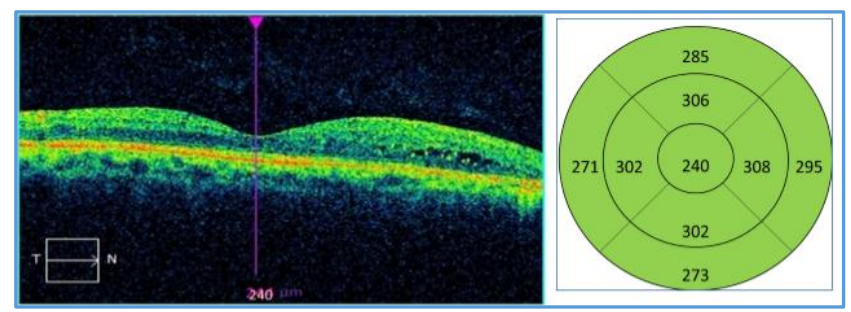

Left Eye OCT before PRP

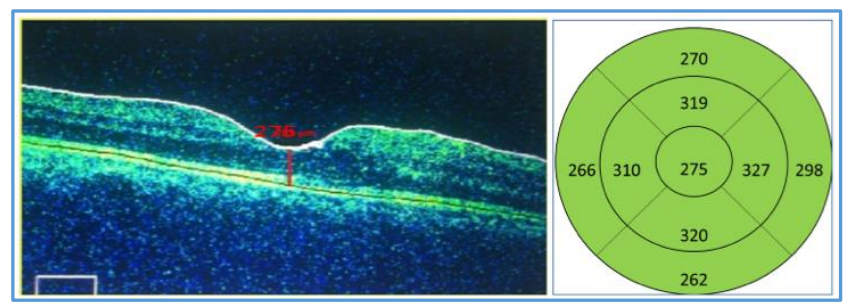

Left Eye OCT at $1^{\text {sT }}$ week after PRP

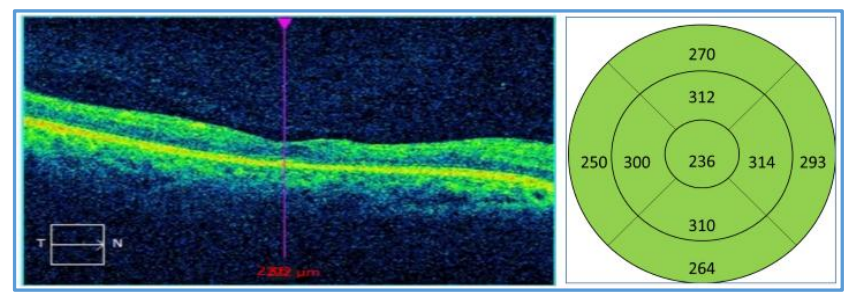

Left Eye OCT at $3^{R D}$ month after PRP

An observational study was conducted on 40 patients from Nov 2015 to Oct 2017. Among the 40 patients included in the study by clinical diagnosis and OCT analysis 16 patients were found to have macular oedema before PRP treatment. Hence, this study analysis was done for 40 patients and between patients with and without macular oedema-

\section{Gender}

- Patients with macular oedema: 9 Females \& 7 Males.

- Patients without macular oedema: 10 Females \& 14 Males.

\begin{tabular}{|c|c|c|}
\hline Patients & $\begin{array}{c}\text { With Macular } \\
\text { Oedema }\end{array}$ & $\begin{array}{c}\text { Without Macular } \\
\text { Oedema }\end{array}$ \\
\hline F & 9 & 10 \\
\hline M & 7 & 14 \\
\hline Grand Total & $\mathbf{1 6}$ & $\mathbf{2 4}$ \\
\hline
\end{tabular}

Age

\begin{tabular}{|c|c|c|c|}
\hline Group & Mean & $\begin{array}{c}\text { Std. } \\
\text { Deviation }\end{array}$ & $\begin{array}{c}\text { T Test } \\
\text { P value }\end{array}$ \\
\hline With Macular Oedema & 61.938 & 5.053 & 0.3179 \\
\hline Without Macular Oedema & 63667 & 5.483 & \\
\hline
\end{tabular}

The patient's age ranged from 55 years to 72 years. Mean age 61.938 years (std. deviation 5.053) with macular oedema and 63.667 years (std. deviation 5.483) without macular oedema.

Table 2. Distribution of cases according to age.

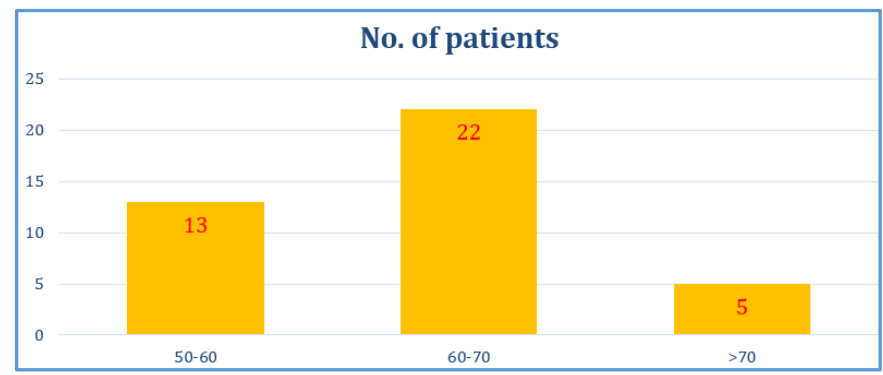

Duration

\begin{tabular}{|c|c|c|c|}
\hline Group & Mean & $\begin{array}{c}\text { Std. } \\
\text { Deviation }\end{array}$ & $\begin{array}{c}\text { T Test } \\
\text { P value }\end{array}$ \\
\hline With Macular Oedema & 18.188 & 4.430 & 0.6102 \\
\hline $\begin{array}{c}\text { Without Macular } \\
\text { Oedema }\end{array}$ & 17.542 & 3.501 & \\
\hline
\end{tabular}

Duration of diabetes for diabetic macular oedema and without diabetic macular oedema the mean was 18.188 (std. deviation 4.430) and mean 18.048 (std. deviation 3.442) respectively and was not statistically significant.

\section{Macular Thickness Analysis}

Mean thickness of macula before PRP was 567.75 (std. deviation 151.713) and 220.792 (std. deviation 24.497) for patients with and without macular oedema respectively.

Patients with macular oedema: At 1 week, 1 month, and 3 months mean macular thickness values were 606.813 (std. deviation 150.800), 491.625(std. deviation 142.795), 292.813(std. deviation 92.937) respectively. p value highly significant $(<0.001)$

\section{Patients without Macular Oedema}

At 1 week, 1 month, and 3 months mean macular thickness values were 309.167(std. deviation 47.578), 267.542 (std. deviation 44.062), 220.167 (std. deviation 40.912) respectively. $\mathrm{P}$ value highly significant $(<0.001)$.

\begin{tabular}{|c|c|c|c|c|c|}
\hline Group & Period & $\mathbf{N}$ & Mean & Std. Dev & P value \\
\hline \multirow{4}{*}{$\begin{array}{c}\text { With } \\
\text { Macular } \\
\text { Oedema }\end{array}$} & Before & 16 & \begin{tabular}{|l}
567.750 \\
\end{tabular} & 151.713 & \multirow{4}{*}{$<0.0001 \mathrm{HS}$} \\
\hline & 1 week & 16 & 606.813 & 150.800 & \\
\hline & 1 month & 16 & 491.625 & 142.795 & \\
\hline & 3 months & 16 & 292.813 & 92.937 & \\
\hline \multirow{4}{*}{$\begin{array}{l}\text { Without } \\
\text { Macular } \\
\text { Oedema }\end{array}$} & Before & 24 & 220.792 & 24.497 & \multirow{4}{*}{$<0.0001 \mathrm{HS}$} \\
\hline & 1 week & 24 & 309.167 & 47.578 & \\
\hline & 1 month & 24 & 267.542 & 44.062 & \\
\hline & 3 months & 24 & 220.167 & 40.912 & \\
\hline
\end{tabular}

\section{Comparison of Macular Thickness Changes}

Mean macular thickness at $1^{\text {st }}$ week, $1^{\text {st }}$ month and $3^{\text {rd }}$ month were compared to mean macular thickness before PRP and their variation were analysed.

Patients with macular oedema: There is sudden increase in macular thickness at $1^{\text {st }}$ week following PRP and thereafter gradually decreases. Macular thickness increases by 39.063 $\mu \mathrm{m}$ (std. deviation 3.32) at $1^{\text {st }}$ week ( $\mathrm{p}$ value $<0.0001$ ) and thickness gradually decreases with $76.125 \mu \mathrm{m}$ (std. deviation 
13.487 ) at $1^{\text {st }}$ month (p value $<0.0001$ ), with $274.93 \mu \mathrm{m}$ (std. deviation 22.368) at $3^{\text {rd }}$ month ( $p$ value $<0.0001$ )

Patients without macular oedema: There is sudden increase in macular thickness at $1^{\text {st }}$ week following PRP and thereafter gradually decreases. Patients with macular thickness increases by $88.375 \mu \mathrm{m}$ (std. deviation -9.375) increase at $1^{\text {st }}$ week ( $\mathrm{p}$ value $<0.001$ ), $46.75 \mu \mathrm{m}$ (std. deviation 8.11 ) at $1^{\text {st }}$ month ( $p$ value $<0.001$ ), and decreases to 0.625 $\mu \mathrm{m}$ (std. deviation 6.775) at $3^{\text {rd }}$ month ( $p$ value $<0.001$ ).

\begin{tabular}{|c|c|c|c|c|c|}
\hline Group & $\begin{array}{l}\text { Paired } \\
\text { Diff }\end{array}$ & $\mathbf{N}$ & Mean & $\begin{array}{l}\text { Std. } \\
\text { Error }\end{array}$ & $P$ value \\
\hline \multirow{3}{*}{$\begin{array}{c}\text { With } \\
\text { Macular } \\
\text { Oedema }\end{array}$} & $\begin{array}{c}\text { Before - } 1 \\
\text { week }\end{array}$ & 16 & -39.063 & 3.320 & \multirow{3}{*}{$<0.0001 \mathrm{HS}$} \\
\hline & $\begin{array}{c}\text { Before - } 1 \\
\text { Month }\end{array}$ & 16 & 76.125 & 0.1543 & \\
\hline & $\begin{array}{c}\text { Before - } 3 \\
\text { Month }\end{array}$ & 16 & 274.938 & 0.0001 & \\
\hline \multirow{3}{*}{$\begin{array}{l}\text { Without } \\
\text { Macular } \\
\text { Oedema }\end{array}$} & $\begin{array}{c}\text { Before - } 1 \\
\text { week }\end{array}$ & 24 & -88.375 & 9.375 & \multirow{3}{*}{$<0.0001 \mathrm{HS}$} \\
\hline & $\begin{array}{c}\text { Before - } 1 \\
\text { Month }\end{array}$ & 24 & -46.750 & 8.110 & \\
\hline & $\begin{array}{c}\text { Before - } 3 \\
\text { Month }\end{array}$ & 24 & 0.625 & 6.775 & \\
\hline
\end{tabular}

Mean macular thickness at 1 month and 3 months were compared to mean macular thickness 1 week after PRP and their changes were analysed:

Though macular thickness had increased at $1^{\text {st }}$ week following PRP, it was not sustained. Macular thickness gradually decreased.

Patients with macular oedema: Macular oedema decreases with mean difference of $115.188 \mu \mathrm{m}$ (std. deviation 13.487 ) at $1^{\text {st }}$ month ( $\mathrm{p}$ value $<0.001$ ), $314 \mu \mathrm{m}$ (std. deviation 22.368 ) at $3^{\text {rd }}$ month ( $p$ value $<0.001$ ).

Patients without macular oedema: Macular oedema decreases with mean difference of $41.625 \mu \mathrm{m}$ (std. deviation 8.110 ) at $1^{\text {st }}$ month ( $\mathrm{p}$ value <0.001), $89.000 \mu \mathrm{m}$ (std. deviation 6.775 ) at $3^{\text {rd }}$ month ( $\mathrm{p}$ value $<0.001$ )

Mean macular thickness at $3^{\text {rd }}$ months were compared to mean macular thickness $1^{\text {st }}$ month after PRP and their changes were analysed

Macular thickness had further decreased at $3^{\text {rd }}$ month when compared at $1^{\text {st }}$ month and were highly significant

Patients with macular oedema: Macular oedema decreases with mean difference of $198.813 \mu \mathrm{m}$ (std. deviation 22.368 ) at $3^{\text {rd }}$ month ( $p$ value $<0.001$ ),

Patients without macular oedema: Macular oedema decreases with mean difference of $47.375 \mu \mathrm{m}$ (std. deviation 6.775 ) at $3^{\text {rd }}$ month ( $p$ value $<0.001$ ).

\begin{tabular}{|c|c|c|c|c|c|}
\hline $\begin{array}{c}\text { Paired } \\
\text { Diff. }\end{array}$ & Group & Mean & $\begin{array}{c}\text { Std. } \\
\text { Deviation }\end{array}$ & \multicolumn{2}{|c|}{$\begin{array}{c}\text { T Test } \\
\text { P Value }\end{array}$} \\
\hline \multirow{2}{*}{$\begin{array}{l}\text { Before -1 } \\
\text { week }\end{array}$} & With ME & -39.063 & 13.279 & $p<0.0001$ & $\mathrm{HS}$ \\
\hline & $\begin{array}{c}\text { Without } \\
\text { ME }\end{array}$ & -88.375 & 45.927 & $\mathrm{p}<0.0001$ & HS \\
\hline \multirow{2}{*}{$\begin{array}{c}\text { Before - } 1 \\
\text { month }\end{array}$} & With ME & 76.125 & 53.948 & $\mathrm{p}<0.0001$ & $\mathrm{HS}$ \\
\hline & $\begin{array}{l}\text { Without } \\
\text { ME }\end{array}$ & -46.750 & 39.729 & $\mathrm{p}<0.0001$ & HS \\
\hline \multirow{2}{*}{$\begin{array}{c}\text { Before - } 3 \\
\text { months }\end{array}$} & With ME & 274.938 & 89.472 & $\mathrm{p}<0.0001$ & $\mathrm{HS}$ \\
\hline & $\begin{array}{c}\text { Without } \\
\text { ME }\end{array}$ & 0.625 & 33.190 & $\mathrm{p}<0.0001$ & HS \\
\hline \multirow{2}{*}{$\begin{array}{l}1 \text { week }-1 \\
\text { month }\end{array}$} & With ME & 115.188 & 52.532 & $\mathrm{p}<0.0001$ & $\mathrm{HS}$ \\
\hline & $\begin{array}{c}\text { Without } \\
\text { ME }\end{array}$ & 41.625 & 23.614 & $\mathrm{p}<0.0001$ & HS \\
\hline
\end{tabular}

\begin{tabular}{|c|c|c|c|c|c|}
\hline \multirow[b]{2}{*}{$\begin{array}{l}1 \text { week }-3 \\
\text { month }\end{array}$} & With ME & 314.000 & 88.733 & $\mathrm{p}<0.0001$ & $\mathrm{HS}$ \\
\hline & $\begin{array}{l}\text { Without } \\
\text { ME }\end{array}$ & 89.000 & 35.717 & $\mathrm{p}<0.0001$ & HS \\
\hline \multirow{2}{*}{$\begin{array}{l}1 \text { month-3 } \\
\text { month }\end{array}$} & With ME & & & & \\
\hline & $\begin{array}{l}\text { Without } \\
\text { ME }\end{array}$ & 47.375 & 21.299 & $\mathrm{p}<0.0001$ & \\
\hline
\end{tabular}

Comparison of Macular Thickness Changes Before and After PRP in Patients With and Without Macular Oedema

\section{DISCUSSION}

1. Among 40 patients who were included in the study, by clinical diagnosis and OCT analysis, 16 patients were found to have macular oedema before PRP treatment. Hence in this study analysis for 40 patients and also between patients with and without macular oedema.

2. Sex distribution $-48 \%$ females and $52 \%$ males

3. The patient's age ranged from 55 years to 72 years. Mean age 61.938 years (std. deviation 5.053) with macular oedema and 63.667 years (std. deviation 5.483) without macular oedema.

4. Duration of diabetics for patients with macular oedema and without diabetic macular oedema were mean 18.188(std. deviation 4.430) and mean 18.048 (std. deviation 3.442) respectively and was not statistically significant.

5. Mean thickness of macula before PRP was 567.750 (std. deviation 151.713) and 220.792(std. deviation 24.497) for patients with and without macular oedema respectively.

6. At 1 week, 1 month, 3 months mean macular thickness values were 606.813 (std. deviation 150.800), 491.625 (std. deviation 142.795), 292.813 (std. deviation 92.937) respectively for patients with macular oedema. $p$ value highly significant $(<0.001)$

7. At 1 week, 1 month, 3 months mean macular thickness values were 309.167 (std. deviation 47.578), 267.542 (std. deviation 44.062), 220.167(std. deviation 40.912) respectively for patients without macular oedema. $\mathrm{p}$ value highly significant $(<0.001)$

8. There is sudden increase in macular thickness at 1 week following PRP and thereafter gradually decreases. Changes in mean macular thickness are analysed in comparison with macular thickness before PRP.

9. Macular thickness changes when compared to before PRP for patients with macular oedema, mean difference of $39.063 \mu \mathrm{m}$ (std. deviation 3.320) increase at 1 week (p value $<0.001$ ) and thickness gradually decreases with $76.125 \mu \mathrm{m}$ (std. deviation 0.1543 ) at 1 month ( $\mathrm{p}$ value $<0.001$ ) and $274.938 \mu \mathrm{m}$ (std. deviation 0.001 at 3 month ( $p$ value $<0.001$ ).

10. Macular thickness variation when compared to before PRP for patients without macular oedema mean difference of $88.375 \mu \mathrm{m}$ (std. deviation 9.375) increase at 1 week (p value <0.001), $46.750 \mu \mathrm{m}$ (std. deviation 8.110 ) at 1 month ( $p$ value $<0.001$ ), and decreases to $0.625 \mu \mathrm{m}$ (std. deviation 6.775) at 3 months ( $p$ value $<0.001$ ).

11. Macular thickness variation when compared 1 week after PRP for patients with macular oedema, there is a decrease in thickness by mean difference of $115.188 \mu \mathrm{m}$ (std. deviation 13.487) at 1 month ( $p$ value $<0.001$ ), with $314.00 \mu \mathrm{m}$ (std. deviation 22.368) at 3 months ( $\mathrm{p}$ value $<0.001)$. 
12. Macular thickness changes when compared 1 week after PRP for patients without macular oedema, there is a decrease in thickness by mean difference of $41.625 \mu \mathrm{m}$ (std. deviation 8.110) at 1 month (p value $<0.001$ ), with $89.000 \mu \mathrm{m}$ (std. deviation 6.775) at 3 months ( $\mathrm{p}$ value $<0.001$ ).

13. Macular thickness changes when compared 1 month after PRP for patients with macular oedema, there is a decrease in thickness by mean difference of $198.813 \mu \mathrm{m}$ (std. deviation 22.368) at 3 months ( $p$ value $<0.001$ ).

14. Macular thickness variation when compared 1 month after PRP for patients without macular oedema, there is a decrease in thickness by mean difference of $47.375 \mu \mathrm{m}$ (std. deviation 6.775) at 3 months ( $p$ value $<0.001$ ).

15. Shimura $M$ et al compared macular thickness and best corrected visual acuity before and after panretinal photocoagulation in patients with severe diabetic retinopathy observed that eyes with severe diabetic retinopathy and good visual acuity PRP did not affect post-operative VA in more than $80 \%$ of patients. patients whose parafoveal thickness was $>300 \mu \mathrm{m}$ before PRP had worst prognosis $(9)$.

16. Soman et al study observed "The effect of PRP on Macular Morphology and Thickness in Eyes with PDR and without Clinically Significant Macular Oedema". PRP was done with standard parameters using green laser in 3-4 sitting with one-week intervals between each. After completion of PRP, patients were followed up at 1 week, 1 month and 3 months. The mean pre-treatment central foveal thickness was $222 \mu \mathrm{m}$. There is increase in central foveal thickness at 1 week following PRP, which remain high at $256 \mu \mathrm{m}$ by 3 months follow up. After PRP, mean vision decrease at one week and one month but stabilized by 3 months. Mean central foveal thickness at final follow up remained high, although the mean visual acuity has normalized at 3 months follow up. Change in central foveal thickness did not correlate with change in visual acuity.(10)

\section{CONCLUSION}

Laser therapy is successful in treatment of DR, which was confirmed by several large randomized studies. PRP may cause transient changes in macular thickness in eyes with Diabetic Retinopathy associated with or without clinically significant macular oedema. The present results suggest that macular oedema increased at 1 week in both the groups and decreased gradually at 1 month and 3 months. Greater rate of reduction of macular oedema was better appreciated in patients with clinically significant macular oedema.

\section{ACKNOWLEDGEMENTS}

I express profound gratitude to Dr. B. Karunakar, MS, Professor, Department of Ophthalmology for his guidance, supervision, scientific aptitude, continuous encouragement and valuable suggestions during the course of the study. I thank all the staff and colleagues for the cooperation and continuous support in referring the cases for this study and their timely suggestions throughout the preparation of this manuscript. I thank all the patients who were involved in the study for the full cooperation which helped in successful completion of the study.

\section{REFERENCES}

[1] Maberley DA. An assessment of risk factors for diabetic retinopathy in the Cree population of James Bay 1999.

[2] Classification Gdrfscfp-aeotmah. Grading diabetic retinopathy from stereoscopic color fundus photographs--an extension of the modified Airlie House classification. ETDRS report number 10. Early Treatment Diabetic Retinopathy Study Research Group. Ophthalmology 1991;98(Suppl 5):786-806.

[3] Group DRSR. Photocoagulation for diabetic macular oedema. Early Treatment Diabetic Retinopathy Study report number 1. Early Treatment Diabetic Retinopathy Study research group. Arch Ophthalmol 1985;103(12):1796-806.

[4] Brucker AJ, Qin H, Antoszyk AN, et al. Observational study of the development of diabetic macular oedema following panretinal (scatter) photocoagulation given in 1 or 4 sittings. Arch Ophthalmol 2009;127(2):13240.

[5] Miyamoto K, Khosrof S, Bursell SE, et al. Prevention of leukostasis and vascular leakage in streptozotocininduced diabetic retinopathy via intercellular adhesion molecule-1 inhibition. Proceedings of the National Academy of Sciences 1999;96(19):10836-41.

[6] Nonaka A, Kiryu J, Tsujikawa A, et al. Inflammatory response after scatter laser photocoagulation in nonphotocoagulated retina. Investigative Ophthalmology and Visual Science 2002;43(4):1204-9.

[7] Wojtkowski M, Fercher AF, Leitgeb R. Phase-sensitive interferometry in optical coherence tomography. LOB00, International Society for Optics and Photonics 2001.

[8] Massin P, Girach A, Erginay A, et al. Optical coherence tomography: a key to the future management of patients with diabetic macular ooedema. Acta Ophthalmologica Scandinavica 2006;84(4):466-74.

[9] Shimura M, Yasuda K, Nakazawa T, et al. Visual dysfunction after panretinal photocoagulation in patients with severe diabetic retinopathy and good vision. American Journal of Ophthalmology 2005;140(1):8.e1-8.e10.

[10] Soman M, Ganekal S, Nair U, et al. Effect of panretinal photocoagulation on macular morphology and thickness in eyes with proliferative diabetic retinopathy without clinically significant macular oedema. Clinical Ophthalmology (Auckland, NZ) 2012;6:2013-7. 